\title{
Effect of Drip Irrigation Levels on Yield of Lettuce under Polyhouse and Open Field Condition
}

\author{
D.T. Santosh*, Raja Gopala Reddy and K.N. Tiwari \\ Agricultural and Food Engineering Department, Indian Institute of Technology, \\ Kharagpur - 721 302, West Bengal, India \\ *Corresponding author
}

\section{A B S T R A C T}

Keywords

Drip irrigation, Lettuce, Crop water requirement, Polyhouse.

Article Info

Accepted:

17 June 2017

Available Online:

10 July 2017
A field experiment was conducted to investigate the effect of irrigation levels using drip irrigation system for Lettuce crop grown under polyhouse and in open field condition during winter season (November-February) for two consecutive years (2014-15 and 201516) at the Experimental Farm area of Precision Farming Development Centre Project, Indian Institute of Technology, Kharagpur, India. Reference evapotranspiration was estimated using FAO-56 Penman Monteith approach. The total water requirement of Lettuce crop was estimated to be $219 \mathrm{~mm}$ and $339 \mathrm{~mm}$ for polyhouse and open field condition respectively. There were total five treatments, four irrigation levels (120\%, $100 \%, 75 \%$ and $50 \%$ of crop water requirement) using drip irrigation system in polyhouse and one treatment $100 \%$ crop water applied through drip in open field condition. The effect of these treatments were studied for biometric and crop yield response. The research trials showed that $100 \%$ of water requirement met with drip irrigation under polyhouse $\left(\mathrm{T}_{2}\right)$ resulted in maximum plant height, head diameter, number of leaves, fresh and dry weight of leaves and crop yield. Open field cultivation produces lowest yield compares to all irrigation level treatments under polyhouse.

\section{Introduction}

Polyhouse provide optimum environmental medium for better crop growth in order to gain maximum yield and high quality products. These require comparatively less land area for agricultural production system resulting in increased land productivity and facilitate year round production of crops.

The main objectives of cultivation of vegetables in a polyhouse condition are, to protect the crop against biotic (pests, diseases and weeds) and abiotic (temperature and humidity light) stresses and to ensure round the year production of high value quality vegetables especially, during the off-season. In India, protected cultivation is a new phenomenon and is still in its initial stage (Rai et al., 2004; Singh and Asrey, 2005).

Irrigation system is one of the most important components affecting the yield and quality of agricultural produce from greenhouse farming system. Water should be given in proper amount and accurate time application. Efficient use of water by irrigation is becoming increasingly important, and alternative water application method such as drip, may contribute substantially to the best 
use of water for agriculture and improving irrigation efficiency. With the drip irrigation systems, water and nutrients can be applied directly to the crop at the root level, having positive effects on yield and water savings and increasing the irrigation performance (Nagaz et al., 2012).

Lettuce (Lactuca sativa L.) is the herbaceous plant that belongs to the Asteraceaes family. It is most popular vegetable consumed as fresh green salad and good source of vitamins and minerals (Stagnari et al., 2015) throughout the world. As lettuce is a short cycle and rapid growth vegetable, it is very demanding in terms of climate conditions, water and nutrients supply; however, it provides fresh mass in rapid increments throughout its cycle. The strengthening of these needs can be better administered by cultivation in protected environments, in which Lettuce can achieve outstanding productions with excellent product quality. It happens because these environments provide a more propitious climate for crop development throughout the year, lessen problems with pests and diseases, protect against climate changes, lower leaching and reduce fertilization costs, enabling thus greater production compared to open environments. However, it is of upmost importance the use of irrigation to reach highest yields.

Despite recent increase in popularity of polyhouse cultivation in India, there is a lack of research on potential exploitation of this technology at different climatic regions, especially with regards to irrigation management. Such studies could optimize irrigation water use, enhancing crop yields and quality, especially for cultivars of high productive capacity. Thus, the present investigation aimed with the determination of the optimum irrigation requirements for Lettuce grown under a poly house in sub humid region and to develop relationship between crop evapotranspiration inside and outside the polyhouse from meteorological parameters.

\section{Materials and Methods}

Field experiment was conducted during winter season (November-February) for two consecutive years (2014-15 and 2015-16) at the Experimental Farm area of Precision Farming Development Centre Project, Agricultural and Food Engineering Department, Indian Institute of Technology, Kharagpur, India. The experimental site is located on flat land at latitude of $22^{\circ} 18.5^{\prime} \mathrm{N}$, longitude $87^{\circ} 19^{\prime} \mathrm{E}$ and altitude of $48 \mathrm{~m}$ above mean sea level. The local climate is subhumid subtropical with an average annual rainfall of $1390 \mathrm{~mm}$, of which about $80 \%$ is received during June to October. The mean monthly minimum temperature is $6{ }^{0} \mathrm{C}$ in January, whereas the mean monthly maximum temperature is $43.5{ }^{\circ} \mathrm{C}$ in May. The mean monthly relative humidity varies from $35 \%$ in February to $96 \%$ during July-August. The soil of the experimental area is lateritic with sandy loam texture.

The meteorological data on significant weather parameter during the crop growth period were collected on daily basis from the meteorological station of Precision Farming Development Centre, IIT Kharagpur. The data includes maximum and minimum temperature, minimum and maximum relative humidity, actual sunshine hour and daily wind speed etc. The daily reference evapotranspiration $\left(\mathrm{ET}_{0}\right)$ was estimated by using FAO based Penman-Monteith (Allen et al., 1998). The daily irrigation water requirement for the Lettuce crops were estimated by using the following relationship

$\mathrm{WR}=\mathrm{ET}_{0} \times \mathrm{Kc} \times \mathrm{Wp} \times \mathrm{A}$

Where,

$\mathrm{WR}=$ Crop water requirement $\left(\mathrm{L} \mathrm{d}^{-1}\right)$ 
$\mathrm{ET}_{0}=$ Reference evapotranspiration $\left(\mathrm{mm} \mathrm{d}^{-1}\right)$ $\mathrm{Kc}=$ Crop coefficient

$\mathrm{Wp}=$ Wetting fraction (taken as 1 for close growing crops)

$\mathrm{A}=$ Plant area, $\mathrm{m}^{2}$ (i.e. spacing between rows, $\mathrm{m} \mathrm{x}$ spacing between plants, $\mathrm{m}$ )

The experiment was conducted in a walking tunnel greenhouse, $17 \mathrm{~m}$ in length and $5 \mathrm{~m}$ in width, with heights at the center and sides of 3.0 and $1.7 \mathrm{~m}$, respectively.

The structure is formed by arched galvanized pipes. The cover is a $200-\mu \mathrm{m}$ thick UV stabilized polyethylene film. The sides are screened with 40 Mesh insect proof net to intercept insects. The polyhouse is positioned in the north/south direction, perpendicular to the path of the sun.

The experiment was laid out in randomized block design (RBD) with five treatments and four replications. The irrigation treatments were based on crop water requirement (CWR) for lettuce crop was calculated by using climatological parameters inside and outside the polyhouse. The detailed of the irrigation treatments are given as under

$\mathrm{T}_{1}$ : Drip irrigation with 120 per cent of CWR inside polyhouse;

$\mathrm{T}_{2}$ : Drip irrigation with 100 per cent of CWR inside polyhouse

$\mathrm{T}_{3}$ : Drip irrigation with 80 per cent of CWR inside polyhouse

$\mathrm{T}_{4}$ : Drip irrigation with 60 per cent of CWR inside polyhouse

$\mathrm{T}_{5}$ : Drip irrigation with 100 per cent of CWR outside polyhouse (open condition).

All treatments were arranged randomly with four replications R1, R2, R3 and R4 for each treatment as a block.

A surface drip irrigation system was designed and installed on an area of $85 \mathrm{~m}^{2}$. The drip system consisted of the following components: Strainer filer, $62 \mathrm{~mm}$ diameter main pipe line (5 m long Poly Vinyl Chloride (PVC) buried at depth of $0.5 \mathrm{~m}$ below ground level), $16 \mathrm{~mm}$ LLDPE lateral line $17 \mathrm{~m}$ long and a pressure compensating drippers of $4 \mathrm{~L}$ $\mathrm{h}^{-1}$ discharge per 4 plants. Lettuce was planted on raised bed. The standard horticultural management practices, such as weed control, protection against pests, etc. were carried out throughout the experiment.

Plant growth parameters measurements were included seasonal increase in plant height, head diameter, the number of green leaves, leaves fresh weight, dry weight and yield was recorded. Statistical analysis was performed using SPSS software package to test the significance of different treatments individually as well as in combinations experimental ANOVA was performed by the method described by Gomez and Gomez (1984). In order to the comparisons between the treatment means and variance were tested at $5 \%$ significance level.

Duncan multiple range test was conducted to know the significance level between the treatments and groups of treatments.

\section{Results and Discussion}

The presence of polyethylene cover causes changes in the climatic conditions compared to those outside during winter season. Radiation and air velocity are reduced; temperature and water vapour pressure of the air increases. Each of these changes has its own impact on the growth, production and quality of the lettuce crop inside the polyhouse. 


\section{Effect of polyfilm on climatic parameters}

Temperature is the major regulator of development processes in crops. Each kind of crop grows and develops most rapidly at a favorable range of air temperatures. This is called the optimum air temperature range. Temperature requirements are usually based on night temperature. Optimum temperature for lettuce crop is $21-29{ }^{0} \mathrm{C}$ during day and $15-20{ }^{0} \mathrm{C}$ during night. Optimum temperature for colour development is $21-24{ }^{0} \mathrm{C}$. Daily variations of maximum and minimum temperature in poly house and for open field condition were recorded from November to February for consecutive two years. Temperature of poly house showed that the use of polyethylene exerted an influence on temperature. Interception of air within the structure increases the daily maximum and minimum temperature compare to outside environment.

Weekly average of daily maximal and minimal air temperatures during the winter season (November to February) in poly house and in open condition are shown in figure 1. Figure 1 shows except starting few weeks Polyhouse recorded the equal or higher value for maximum or minimal air temperatures compare to open condition. Weekly average of daily maximal temperature for the winter season shows that highest value of maximal temperature recorded in polyhouse for the second week after transplantation $\left(42{ }^{\circ} \mathrm{C}\right)$. In the month of January ( 8 weeks after transplantation) polyhouse recorded almost same value of minimal and maximal temperature as in open condition. It also observed that $8 \%$ increase in mean temperature of polyhouse compare to the open condition. Poly film increases the temperature by accumulation of solar radiation inside structures.

Figure 2 shows that the daily mean relative humidity increased in poly house by $3-16 \%$ as compared with open field. During extreme winter of December and January (6-12 weeks after transplantation) more humidity observed in polyhouse compares to open condition. These results were in line with those reported by Igle-sias and Alegre (2006), indicating a 3-9\% increase in humidity associated with the use of poly films. These authors also reported a decrease in evaporation associated with the use of cladding materials and a significant reduction in wind speed. During the experiment, average temperature and air relative humidity in side greenhouse were $24.8^{\circ} \mathrm{C}$ and $58.5 \%$, respectively. The referred temperature is close to the optimum range recommended by Santana et al., (2009), standing within 15 and $25{ }^{\circ} \mathrm{C}$ for great lettuce development; however, it is still reported that, when cultivated in warm climate and summer, this plant does not reach its full genetic potential.

Figure 3 shows that poly film transmits solar radiations about 60 to $80 \%$ depending upon the sunshine hours. During extreme winter of December and January (8-12 weeks after transplantation) small difference $(20 \%)$ in receiving net radiations by plant was observed between polyhouse and open condition. As the temperature increases during February month (14-18 weeks after transplantation) this difference of receiving solar radiations is also increases upto $40 \%$. The cladding materials covering on polyhouse, significantly changes the radiation balance relatively to the external environment, because of the attenuation (absorption and reflexion) of the incident solar radiation, resulting in a reduction of the internal radiation balance and, consequently, affecting evapotranspiration (Sentelhas, 2001).

\section{Reference evapotranspiration}

Application of FAO-56 Modified PenmanMonteith (PM) equation was used for estimating Lettuce crop water requirement, 
the microclimate data plays an important role for irrigation planning. With the appropriate climatic data measured in the greenhouse, crop water requirement could be predicted using the evapotranspiration equation from PM model.

This method was also applied to the greenhouses by other researchers (Chartzoulakis and Drosos, 1997; Baille, 1994). Evapotranspiration under polyhouse tended to be lower than open field because of the greenhouse effect and the low radiation under these covers.

Polyethylene sheet cover obtained the highest air temperatures and open field recorded the highest evapotranspiration during the whole season, which agreed with the results reported by Abdrabbo (2001) and Salman et al., (1992). The difference between internal and external evapotranspiration varies according to meteorological conditions.

Seasonal $\mathrm{ET}_{0}$ of polyhouse is quite low when compared to that of irrigated crops outdoors during winter. The values of $\mathrm{ET}_{0}$ ranges from 1.8 to $2.5 \mathrm{~mm} \mathrm{day}^{-1}$ for 14 weeks were estimated for the poly house which is much lower compares to open condition.

Many authors have also observed that evapotranspiration inside a greenhouse is around 60 to $80 \%$ of that verified outside (Rosenberg et al., 1989). Farias et al., (1994) observed that the reference evapotranspiration $\left(\mathrm{Et}_{0}\right)$ inside greenhouses was always lower, ranging on 45 to $77 \%$ of that verified outside.

Braga and Klar (2000) observed that the values of reference evapotranspiration were 85 and $80 \%$ of the reference evapotranspiration verified outside for greenhouses oriented east/west and north/south, respectively. These results can be explained by the influence of the main factors of evaporative demand of the atmosphere, such as lower wind speed values, higher relative humidity and lower incidence of direct solar radiation inside greenhouses.

Relation between
evapotranspiration $\left(\mathrm{ET}_{\mathbf{0}}\right)$ inside and
outside the polyhouse

Regression analysis between daily reference evapotranspiration $\left(\mathrm{ET}_{0}\right)$ inside and outside the polyhouse during the experiment is depicted in figure 5. The relationship between the reference evapotranspiration inside and outside the shade net house was found to be

$\mathrm{ET}_{0}$ Open $=1.9264 \mathrm{ET}_{0}$ in -0.7592

Where,

$\mathrm{ET}_{0}$ Open $=$ Reference evapotranspiration outside the polyhouse, ( $\mathrm{mm}$ )

$\mathrm{ET}_{0}$ in $=$ Reference evapotranspiration inside the polyhouse, (mm).

The co-efficient of determination $\left(\mathrm{R}^{2}\right)$ between crop evapotranspiration $\left(\mathrm{ET}_{0}\right)$ inside and outside the polyhouse was found to be 0.8415 during the growth period. However the correlation between $\mathrm{ET}_{0}$ inside and outside the polyhouse $(r=0.917)$ at was highly significant.

Results show that the reference evapotranspiration inside the polyhouse $\left(\mathrm{ET}_{0}\right.$ in) values were lower than reference evapotranspiration outside the polyhouse $\left(\mathrm{ET}_{0}\right.$ open).

During the initial stage of crop, $\mathrm{ET}_{0}$ in is greater than the $\mathrm{ET}_{0}$ open. At middle and late stages, $\mathrm{ET}_{0}$ open was gradually increased. On an average, the $\mathrm{ET}_{0}$ in was about 70 per cent of the $\mathrm{ET}_{0}$ open. It is clear that crop water requirement in the polyhouse was less than crop water requirement outside the polyhouse. 
Fig.1 Weekly average of daily maximum and minimum temperature recorded during the period of experimentation in polyhouse and open condition

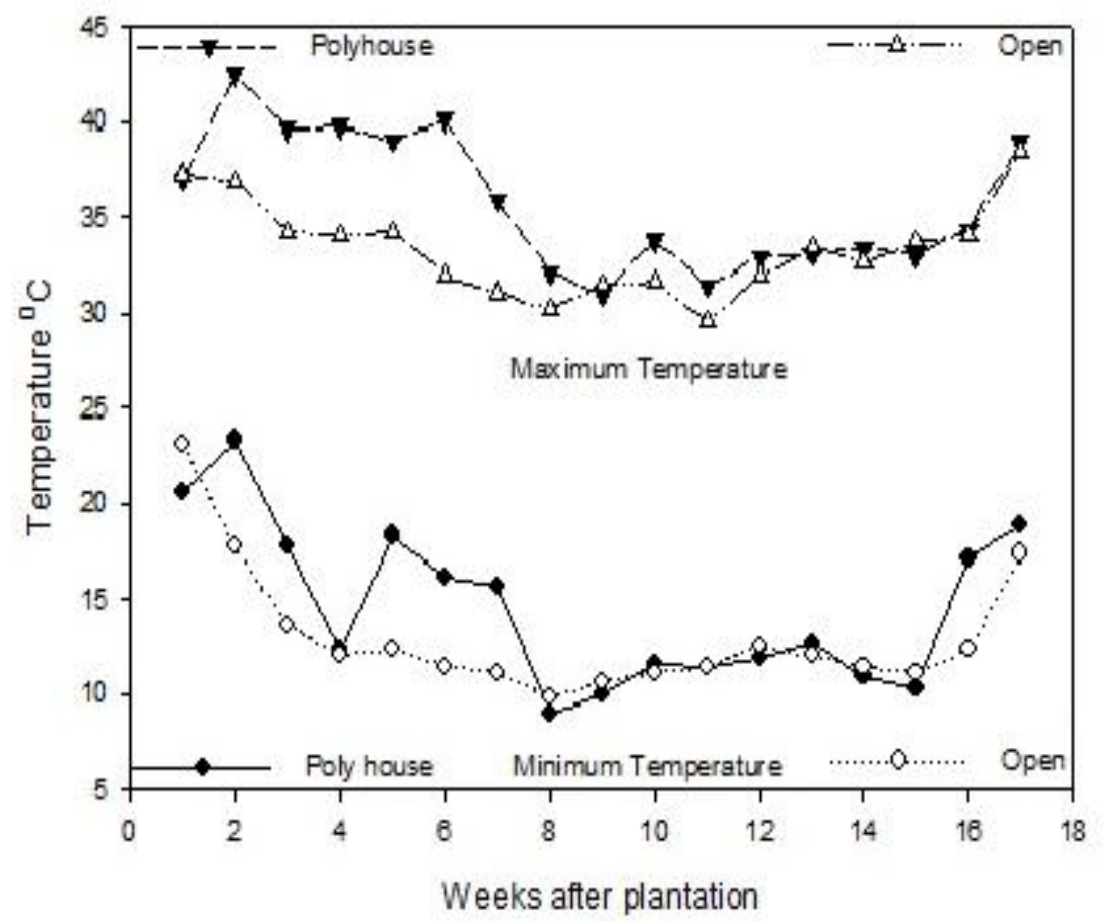

Fig.2 Weekly average of daily mean relative humidity recorded during the period of experimentation in polyhouse and open condition

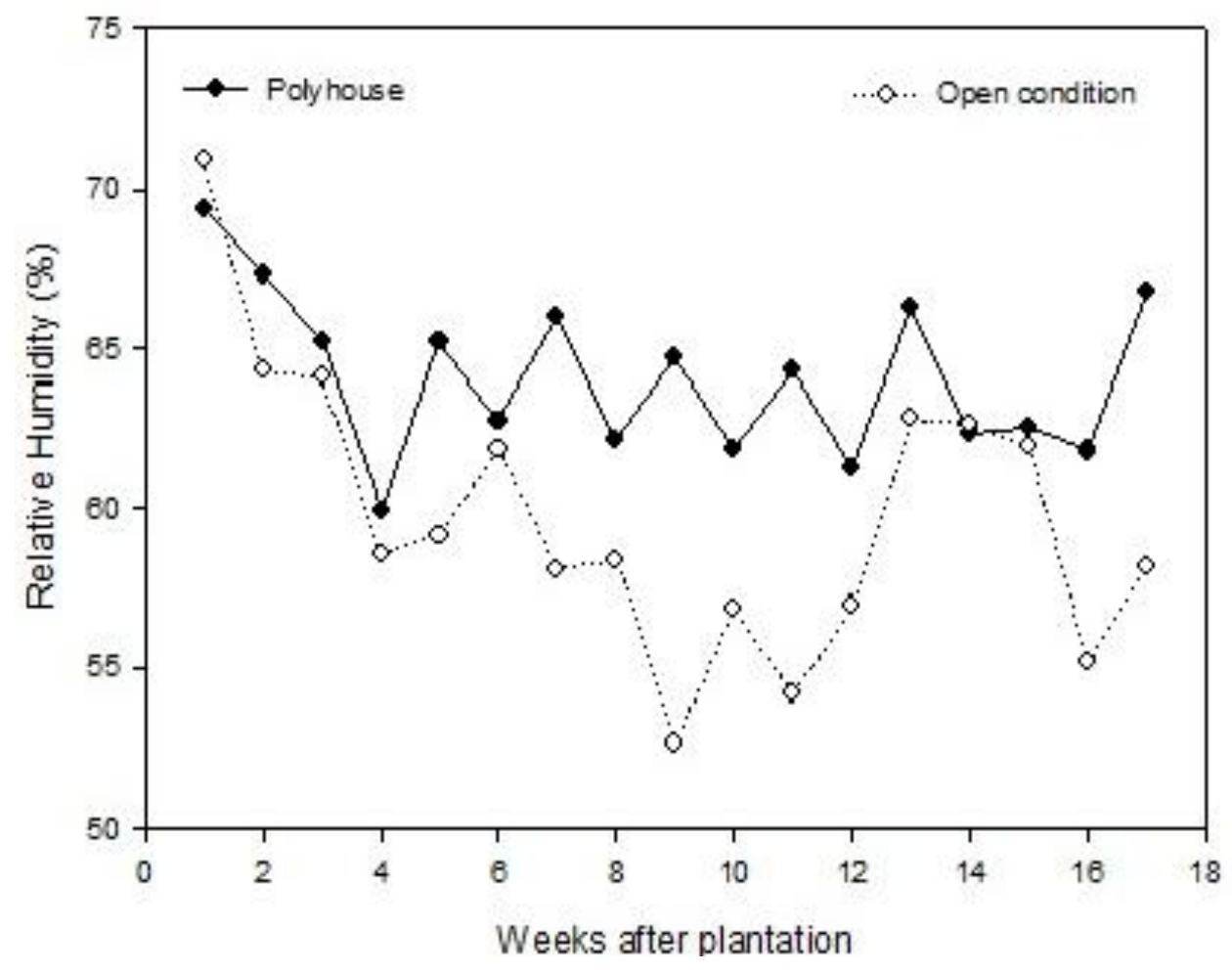


Fig.3 Weekly average of daily Radiation $\left(\mathrm{W} \mathrm{m}^{-2}\right)$ recorded during the period of experimentation in polyhouse and open condition

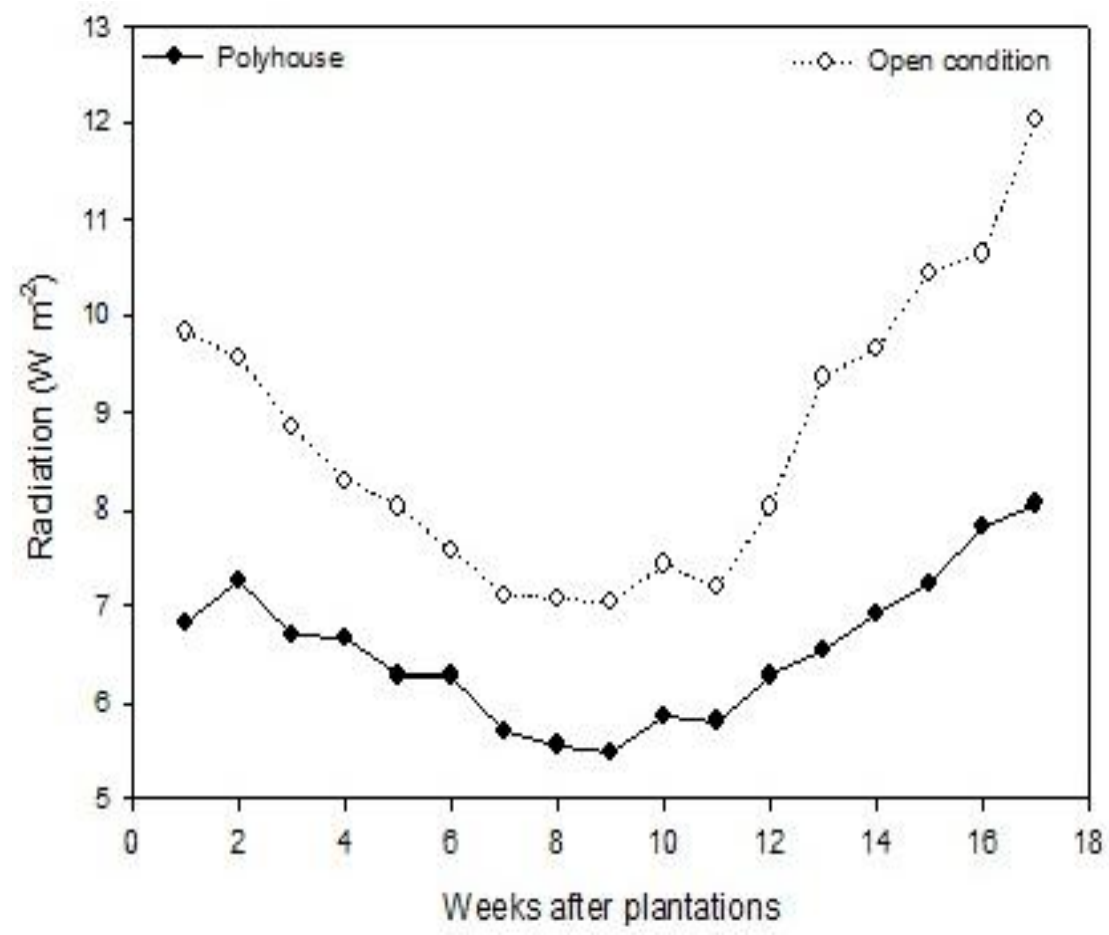

Fig.4 Weekly average of daily reference evapotranspiration $\mathrm{ET}_{0}(\mathrm{~mm})$ estimated for the period of experimentation in polyhouse and open condition

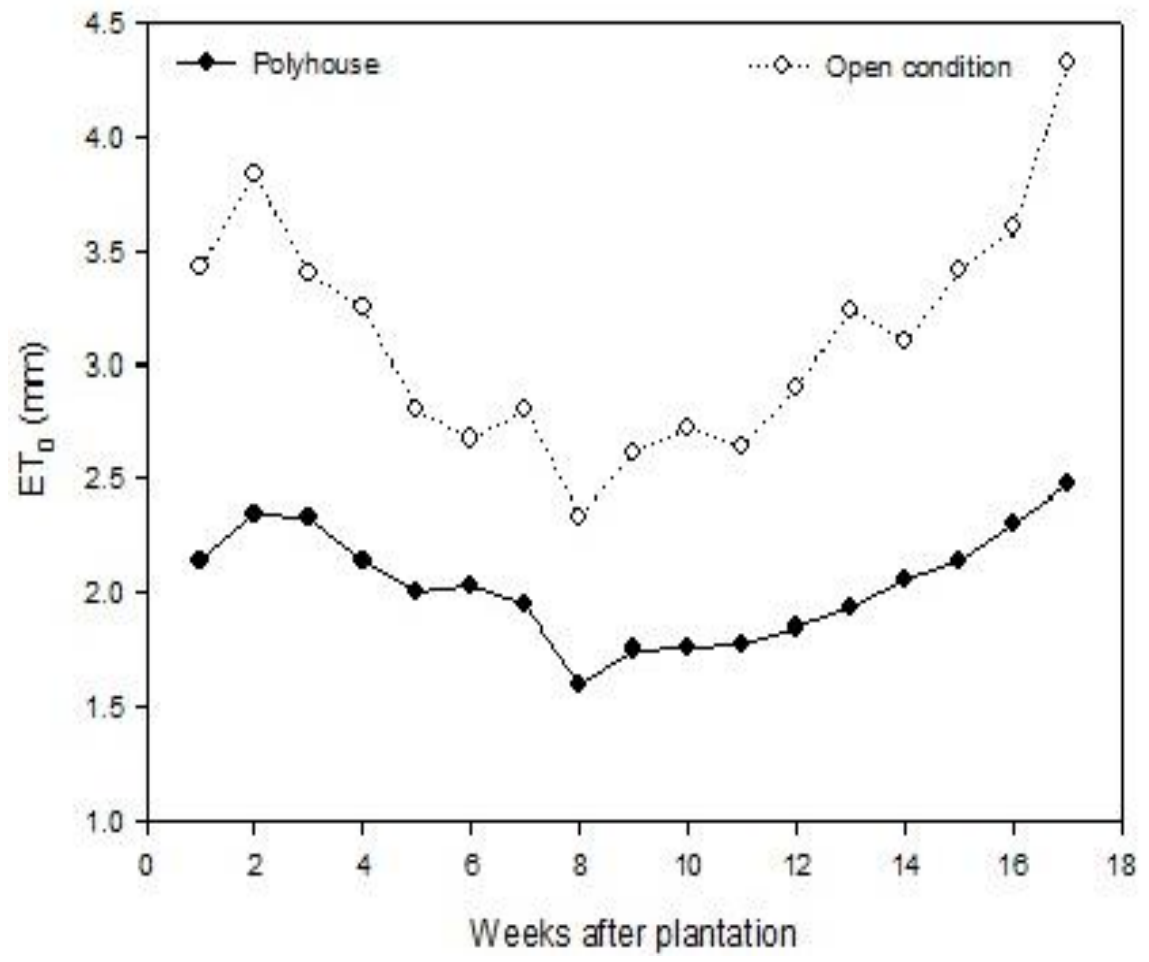


Fig.5 Relation of daily reference evapotranspiration inside and outside the polyhouse

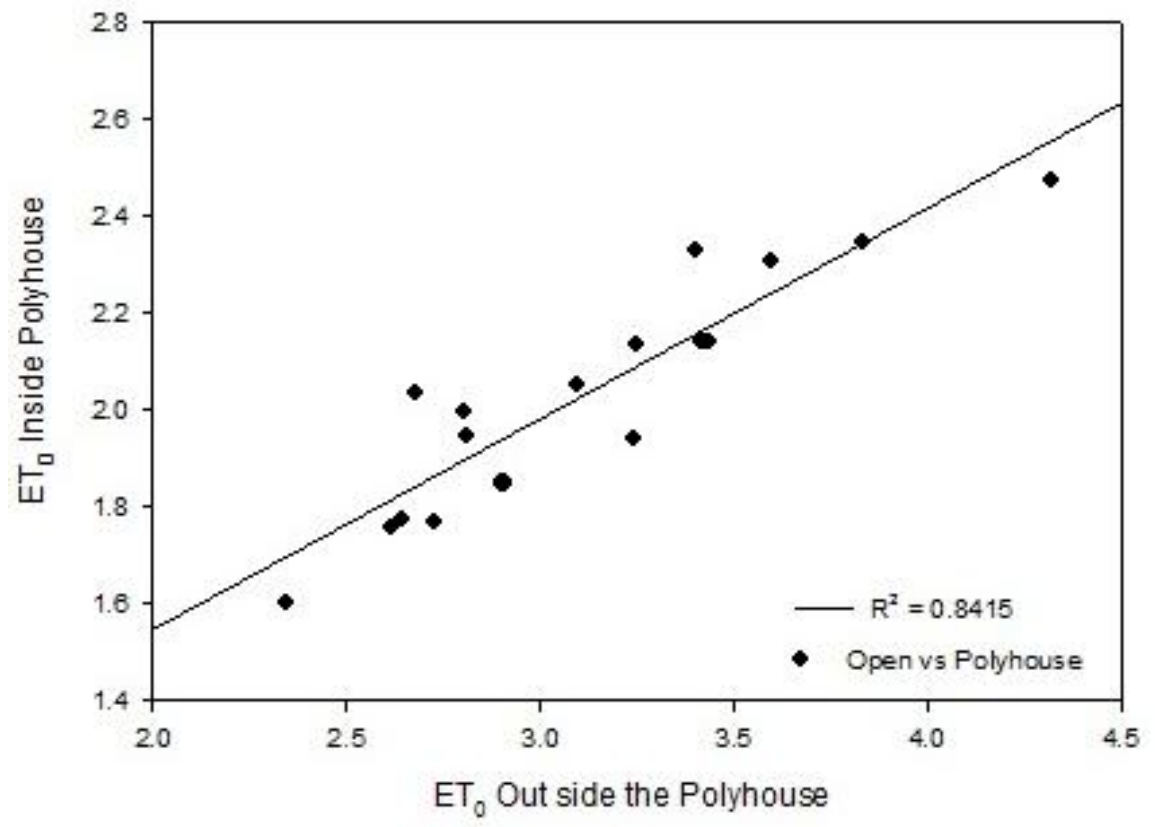

Table.1 Effect of irrigation levels on biometric parameters and yield of Lettuce crop (pooled data of two season 2014-15 and 2015-16)

\begin{tabular}{|c|c|c|c|c|c|c|}
\hline Treatment & $\begin{array}{c}\text { Plant } \\
\text { Height } \\
\text { (cm) }\end{array}$ & $\begin{array}{c}\text { Head } \\
\text { Diameter } \\
(\mathbf{c m})\end{array}$ & $\begin{array}{c}\text { Leaves (No. } \\
\text { plant }^{-1} \text { ) }\end{array}$ & $\begin{array}{c}\text { Leaves } \\
\text { Fresh } \\
\text { Weight } \\
\left.\text { (g plant }^{-1}\right)\end{array}$ & $\begin{array}{c}\text { Leaves } \\
\text { Dry } \\
\text { Weight }\left(g^{-1}\right. \\
\left.\text { plant }^{-1}\right)\end{array}$ & $\begin{array}{c}\text { Yield (t } \\
\left.h^{-1}\right)^{-1}\end{array}$ \\
\hline $\mathrm{T} 1(120 \% \mathrm{WR}+\mathrm{PH})$ & $32.08 \mathrm{ab}$ & $13.33 \mathrm{a}$ & $30.73 \mathrm{a}$ & $399.65 \mathrm{a}$ & $35.63 \mathrm{a}$ & $31.70 \mathrm{ab}$ \\
\hline $\mathrm{T} 2(100 \% \mathrm{WR}+\mathrm{PH})$ & $36.30 \mathrm{a}$ & $13.49 \mathrm{a}$ & $31.75 \mathrm{a}$ & $409.20 \mathrm{a}$ & $38.23 \mathrm{a}$ & $35.73 \mathrm{a}$ \\
\hline $\mathrm{T} 3(75 \% \mathrm{WR}+\mathrm{PH})$ & $31.80 \mathrm{ab}$ & $11.17 \mathrm{ab}$ & $28.53 \mathrm{ab}$ & $357.35 \mathrm{~b}$ & $28.65 \mathrm{~b}$ & $29.53 \mathrm{ab}$ \\
\hline $\mathrm{T} 4$ (50\% WR+PH) & $30.30 \mathrm{ab}$ & $10.36 \mathrm{~b}$ & $25.70 \mathrm{ab}$ & $331.68 \mathrm{~b}$ & $26.40 \mathrm{~b}$ & $26.43 \mathrm{~b}$ \\
\hline T5 (100\% Open) & $26.10 \mathrm{~b}$ & $9.77 \mathrm{~b}$ & $22.45 \mathrm{~b}$ & $291.68 \mathrm{c}$ & $23.73 \mathrm{~b}$ & $18.15 \mathrm{c}$ \\
\hline CV $(\%)$ & 15.9 & 12.9 & 14.1 & 5.5 & 12.77 & 17.60 \\
\hline
\end{tabular}

$\mathrm{WR}=$ water requirement of crops; $\mathrm{PH}=$ polyhouse

Note: Differences among the means with the same letter are insignificant based on Duncan's test $(\mathrm{p}<0.05)$

Irrigation water requirement of lettuce crop

The crop evapotranspiration was estimated by multiplying reference evapotranspiration with crop coefficient based on crop growth stage. In present study the value for crop coefficient (Kc) was taken from FAO-50 (Allen et al., 1998). The irrigation water requirement of lettuce crop using drip irrigation was estimated for polyhouse $\left(0.25-0.331\right.$ plant $^{-1}$ Day $\left.^{-1}\right)$ and open field condition $(0.66-0.891$ plant $^{-1}$ Day $^{-1}$ ) cultivation. Seasonal water requirement of Lettuce crop using drip irrigation under polyhouse is estimated as 219 $\mathrm{mm}$ and $339 \mathrm{~mm}$ for open field condition.

\section{Growth and yield of lettuce}

Two years pooled data of biometric parameters like plant height, head diameter, number of leaves per plant, leaves fresh weight, leaves dry weight and yield of Lettuce crop are presented in table 1 . The results from 
table 1 revealed that, biometric parameters and yield are significantly superior in the treatment $\mathrm{T}_{2}(100 \%$ crop water requirement through drip irrigation in polyhouse) as compared to the rest of the treatments inside polyhouse and for open condition treatment. The height of plant under treatment $\mathrm{T}_{2}(36.3$ $\mathrm{cm})$ was found to be significantly highest among all other treatments and is 39\% higher than the height of plant cultivated outside polyhouse with drip irrigation $\left(\mathrm{T}_{5}\right)$.

The head diameter recorded as 13.33, 13.49, 11.17, 10.36 and $9.77 \mathrm{~cm}$ for $\mathrm{T}_{1}, \mathrm{~T}_{2}, \mathrm{~T}_{3}, \mathrm{~T}_{4}$ and $\mathrm{T}_{5}$ treatments respectively. It also observed that about $38 \%$ higher head diameter of lettuce found in polyhouse compare to outside the polyhouse treatment. As regards to number of leaves per plant, maximum numbers of leaves found in treatment $T_{2}$ (31.7) followed by treatment $T_{1}$ (30.7) and the lowest value was found in treatment $\mathrm{T}_{5}$ (20.45). The primary effect of reduction in irrigation level on lettuce growth was the reduction of leaf area as a consequence of leaf number reduction. It was also observed that increases in the leaf number under drip irrigation system with optimum water application might have resulted due to the better water utilization and excellent soil-water-air relationship with higher oxygen concentration in the root zone (Gornat et al., 1993). When the quantity of water through the drip irrigation was reduced, lettuce leaf number decreased significantly.

Lettuce leaf fresh weight and dry weight found higher in crop irrigated with 100\% irrigation requirement inside polyhouse. Leaves fresh and dry weight of the well irrigated plants (100\% irrigation water) inside greenhouse weighed about $409 \mathrm{~g}$ and $38.3 \mathrm{~g}$ whereas treatments $\mathrm{T}_{5}(100 \%$ irrigation water requirement in open condition) showed reductions of 40 and $60 \%$, respectively. Karam et al., (2002) reported that reduction in application of irrigation water reduced significantly in fresh weight of individual heads $(\mathrm{P}<0.05)$.

The analysis of observations showed that different levels of irrigation with drip responded differently to yield of crop. Data indicates that irrigation treatment $\mathrm{T}_{2}$ produced highest yield of $35.73 \mathrm{t} \mathrm{ha}^{-1}$. The effect of irrigation levels on yield has been investigated and similar results reported by Jordan et al., (2003). Bozkurt et al., (2009) indicated that irrigation levels had significant influence on yield and yield components of lettuce crop. Similarly, it can be seen that yield of lettuce $\left(18.5 \mathrm{t} \mathrm{ha}^{-1}\right)$ was recorded to be the lowest for treatment of $100 \%$ irrigation water application in open condition $\left(\mathrm{T}_{5}\right)$. The increase in yield as a response to polyhouse is probably due to enhanced availability of water, humidity and carbon dioxide which enhanced more leaf area resulting in higher photo assimilates, thereby more dry matter accumulation. Leaf expansion, leading to increased interception of daily solar radiation by the canopy. Kirnak et al., (2016) also reported similar findings, which indicated that controlled environment significantly influenced growth and yield of lettuce.

In conclusion, Present study shows that lettuce production in winter for sub humid region is fatal due to fall of temperature below optimum level which results in deficient growth. Polyhouse offer a great solar energy saver and increased temperature inside structures from the above data we can conclude that, lettuce production in open field condition requires higher irrigation water comparing to polyhouse cultivation. It also shows that $35.2 \%$ less irrigation water require for poly house cultivation comparing to irrigation water requirement for open field cultivation. The optimum temperature accompanied by low relative humidity at initial stage and low temperature and high 
humidity at later stage with low solar intensity inside polyhouse provide the most suitable growing environment for lettuce, so growers are benefited by being able to produce higher lettuce which can be fetched premium prices in the market. Seasonal water requirement of Lettuce crop using drip irrigation under polyhouse was estimated $219 \mathrm{~mm}$ and 339 $\mathrm{mm}$ for open field condition. Results also revealed that about $98 \%$ higher yield obtained under polyhouse compare to open field condition.

\section{Acknowledgement}

Authors are thankful to the National Committee on Plasticulture Application in Horticulture (NCPAH), Department of Agriculture and Cooperation, Ministry of Agriculture, Government of India for providing necessary funds to conduct this research studies.

\section{References}

Abdrabbo, M.A.A., (2001). Effect of shading on cucumber productivity under greenhouses. M.Sc. Thesis. Ain Shams University, Cairo, Egypt, p. 86.

Allen, R.G., Pereira, L.S., Raes D. and Smith, M. (1998). Crop evapotranspiration: Guidelines for computing crop requirements. Irrigation and Drainage Paper No. 56, FAO, Rome, Italy.

Asrey, R., Singh, R. 2005, Low cost polyhouse technology for off-season vegetable production, ICAR NEWS, 11: April-June 2005.

Baille. A. (1994). Principal and methods for predicting crop water requirement in greenhouse environments, INRACIHEAM, Cahiers Options Mediterraneennes, 3, pp. 177-186.

Bozkurt, S., Mansuro, G.S., Kara, M. and Onder, S. (2009). Responses of Lettuce to Irrigation Levels and Nitrogen
Forms. African J. Agric. Res. Vol.4, pp.1171-77.

Braga, M.B., Klar, A.E. (2000). Evaporation de referÍncia em campo e estufa orientadas nos sentidos norte/sul e leste/oeste. Irriga, v.5, p.222-228.

Chartzoulakis, K. Drosos, N. (1997). Water requirements of greenhouse grown pepper under drip irrigation. Acta Hort. (ISHS), 449, pp. 175-180.

Dunage, V., Balakrishnan, P. and Patil, M. (2010).Water use efficiency and economics of tomato using drip irrigation under netthouse conditions. Karnataka J. Agric. Sci., 22(1): 133136.

Farias, J.R.B., Bergamaschi, H., Martins, S.R. (1994). Evapotranspiration interior de estufas pl-sticas. Revista Brasileira de, Agrometeorologia, v.2, p.17-22.

Gomez, K.A. and Gomez, A.A., 1984. StatisticalProcedures for Agricultural Research.John Wileyand Sons.New York pp. 91-115.

Gornat, B., Goldberg, D., Rimon, D., Asher Ben J. (1993). The physiological effect of water quality and method of application on tomato, cucumber and pepper. J. Am. Soc. Hort. Sci. 98(2): 202-205.

Harmanto, Salokhe V., Babel, M. and Tantau, H. (2005). Water requirement of drip irrigated tomatoes grown in greenhouse in tropical environment. Agric. Water Mgmt., 71(3): 225-242.

Iglesias, I., and S. Alegre. (2006). The effect of anti-hail nets on fruit production, radiation, temperature, quality and profitability of 'Mondial Gala' apples. Journal of Applied Horticulture 8:91100.

Jordan, J.E., White, R.H., Victor, D.M., Hale, T.C., Thomas, J.C. and Engelke, M.C. (2003). Effect of irrigation frequency on turf quality, shoot density, and root length density of five Bentgrass 
cultivars, Crop Sci.Vol.43, pp.282-87.

Karam, F., Mounzer, O., Sarkis, F., Lahoud, R. (2002). Yield and nitrogen recovery of lettuce under different irrigation regimes. J. Appl. Hort., 4(2): 70-76.

Kirda, C. (2002).Deficit irrigation scheduling based on plant growth stages showing water stress tolerance, Deficit Irriga. Practices, FAO Water Reports, 22: 3 10.

Kirda, C., Cetin, M., Dasgan, Y., Topcu, S., Kaman, H., Ekici, B., Derici, M.R. and Ozguven, A.I. (2004). Yield response of greenhouse grown tomato to partial root drying and conventional deficit irrigation. Agric. Water Manage, 69(1): 191-201.

Kirnak, H., Taş, I., Gökalp, Z. and Karaman, S. (2016). Effects of different irrigation levels on yield of lettuce grown in an unheated greenhouse. Current Trends in Natural Sciences, 5(9):145-151.

Nagaza K., Masmoudib, M. M., Mechliab, N.B. (2012). Impacts of irrigation regimes with saline water on carrot productivity and soil salinity. Journal of the Saudi Society of Agricultural Sciences, 11(1): 19-27.

Patanè, C. and Cosentino, S. (2010). Effects of soil water deficit on yield and quality of processing tomato under a Mediterranean climate. Agric. Water Mgmt., 97(1): 131-138.

Rai, N., Nath, A., Yadav, D.S. and Patel, K.K. 2004. Effect of polyhouse on shelf-life of bell pepper grown in Meghalaya. National Seminar on Diversification of Agriculture through Horticultural
Crops, held at IARI Regional Station, Karnal, from 21-23 ${ }^{\text {rd }}$ February, pp. S.P.22

Rosenberg, N.J., Mckenney, M.S., Martin, P. (1989). Evapotranspiration in a greenhouse-warmed world: a review and a simulation. Agricultural and Forest Meteorology, v.47, p.303-320.

Salman, S.K., Abou-Hadid, A.F., Beltagy, I.M.J., Beltagy, A.S., (1992). Plastic house microclimate as affected by low tunnels and plastic mulch. Egypt. J. Hort. 2, 111-119.

Santana, S.M., Dias-Arieira, C.R., Biela, F., Cunha, T.P.L., Chiamolera, F.M., Roldi, M. (2012). Antagonistic plants in the management of Meloidogyne incognita in sandy soil of vegetables growing areas. Nematropica 42: 287-294.

Sentelhas, P.C. (2001). Agrometeorologia aplicada à irrigação. In: MIRANDA, J.H.; PIRES, R.C. de M. Irrigação. Piracicaba: FUNEP. P.63-120.

Stagnari, F., Galiene, A., and Pisante, M. (2015). Shading and nitrogen management affect quality, safety and yield of greenhouse-grown leaf lettuce. Scientia Horticulturae, 192(31), 70-79.

Tiwari, G.N. (2003). Greenhouse technology for controlled environment. Narosa Publishing House, New Delhi, 67-77pp. Tiwari, K.N., Singh, A. and Mal, P.K. (2000). Economic feasibility of raising seedlings and vegetables production under low cost plastic tunnel. International Committees of Plastics in Agriculture (CIPA), Paris, plasticulture on-line publication.

\section{How to cite this article:}

Santosh, D.T., Raja Gopala Reddy and Tiwari, K.N. 2017. Effect of Drip Irrigation Levels on Yield of Lettuce under Polyhouse and Open Field Condition. Int.J.Curr.Microbiol.App.Sci. 6(7): 1210-1220. doi: https://doi.org/10.20546/ijcmas.2017.607.146 